\title{
A technológiai fejlődés lehetséges munkahelyteremtő-, és romboló hatásai
}

\section{The Possible Job Creation and Job Destructive Effects of Technological Development}

\section{J. BOROS}

Debreceni Egyetem, Gazdaságtudományi Kar, Vezetés- és Szervezéstudományi Intézet, Emberi Erőforrás Menedzsment tanszék, boros.jozsef@econ.unideb.hu

Absztrakt. A történelem során a technológiai változások gyakran a munkavállalói szorongások alapját szolgálták. 1811 és 1816 között Angliában a munkavállalók egy csoportja - akik „Luddistáknak” nevezték magukat - tönkretették azokat a gépeket, amelyekrôl azt gondolták, hogy veszélyeztetik a munkahelyüket. A 19. századi gondolkodók és közgazdászok, mint Karl Marx és David Ricardo azt jósolták, hogy a gazdaság gépesítése végső soron a munkavállalói körülményeket rontaná, megfosztva őket attól, hogy egy elfogadható szintü bérből élhessenek. Az elmúlt évszázadban John M. Keynes (az 1930-as években) és Wassily Leontief (az 1950-es években) azon félelmüket fogalmazták meg, hogy egyre több és több munkást váltanak ki gépi megoldásokkal, amely munkanélküliséghez vezet. Az utóbbi években Brynjolfsson és McAfee (2014) állította, hogy a jelenlévő technológiák csökkentik a munkaerő iránti keresletet és az emberi munkaerô egy részét tartós hátrányba sodorják. Azonban számos kompenzációs mechanizmus létezik, amelyek ellensúlyozhatják az automatizálás és általában a folyamatinnováció kezdeti munkaerő-kiszorító hatásait (Vivarelli, 2015). Először is, miközben a munkavállalókat kiváltják azokban az iparágakban, amelyekben bevezetik az új gépekbe épített technológiát, további munkavállalókra van szükség az új gépeket gyártó iparágakban. Másodszor, az automatizálás (és általánosságban a folyamatinnováció) csökkenti az átlagos költségeket. Acemoglu és Restrepo (2017) azt állapították meg, hogy ez egyrészrôl ár-termelékenységi („priceproductivity”) hatást eredményez (mivel a termelési költségek csökkennek, az iparág kibövítheti és növelheti munkaerő-igényét); és másrészről a termelés méretgazdaságossági hatásához vezet (az automatizálás miatti költségcsökkenés a teljes kibocsátás növekedéséhez vezet, és minden iparágban növeli a munkaerő iránti igényt). Hasonlóképpen, Vivarelli (2015) azzal érvel, hogy az alacsonyabb átlagköltségek alacsonyabb árakat eredményezhetnek (ha az ipar piaci struktúrája tökéletesen versenyképes), stimulálják a termékkeresletet, vagy extra nyereséget eredményezhetnek (ha az ipar szerkezete nem tökéletesen versenyképes). Ha ezeket az extra nyereségeket újra befektetik a cégbe, ez a beruházás új munkahelyeket teremthet. Az előadás ezen ellensúlyozó eseteket szándékozik bemutatni és valós példákkal alátámasztani a szakirodalom alapján.

Abstract. Throughout history, technological change has often provided the basis for employee anxiety. Between 1811 and 1816, a group of workers in England who called themselves "Luddists" destroyed machines, because they thought it would endanger their workplace. 19th-century thinkers and 
economists such as Karl Marx and David Ricardo predicted that mechanizing the economy would ultimately worsen workers' conditions, depriving them of a decent wage. Over the last century, John M. Keynes (1930s) and Wassily Leontief (1950s) have expressed their fears that more and more workers will be replaced by machine solutions that will lead to unemployment. In recent years, Brynjolfsson and McAfee (2014) have argued that existing technologies reduce the demand for labor and put some of the human workforce at a permanent disadvantage. However, there are a number of compensation mechanisms that can offset the initial displacement effects of automation and process innovation in general (Vivarelli, 2015). First of all, while workers are being replaced in industries that introduce new machine technology, additional workers in new industries are needed. Second, automation (and process innovation in general) reduces average costs. Acemoglu and Restrepo (2017) found that this results, on the one hand, in the effect of price productivity ("priceproductivity") (as production costs decrease, the industry can expand and increase labor demand); and, on the other hand, it leads to economies of scale in production (the reduction in costs due to automation leads to an increase in total output and increases the demand for labor in all industries). Similarly, Vivarelli (2015) argues that lower average costs can result in lower prices (if the industry's market structure is perfectly competitive), stimulate product demand, or result in extra profits (if the industry's structure is not perfectly competitive). If these extra profits are reinvested in the company, this investment can create new jobs. The presentation intends to

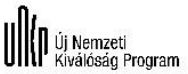
present these counterbalancing cases and to provide real examples based on the literature.

„Az Innovációs és Technológiai Minisztérium ÚNKP-19-3 kódszámú Új Nemzeti Kiválóság Programjának szakmai támogatásával készült."

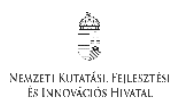

\section{Bevezetés}

A történelem során több alkalommal is láthattunk példát arra, hogy a jelentős technológiai fejlődésbeli ugrások milyen felforgató erővel bírnak a meglévő társadalmi és gazdasági berendezkedésekben. Ha csak az elmúlt évszázadokat nézzük és Ford (2017) munkáját vesszük alapul, akkor is találunk arra vonatkozó esetet, hogy hogyan vándorolt a mezőgazdaságban dolgozók egy jelentős része a gépesítés következtében a nagyvárosokba és töltött be valamilyen szerepet a gyárak működésében. Az egyre növekvő automatizálás és a globalizáció eredményeként azonban ezen munkaerő is kiváltható, aminek következtében az iparban dolgozók részaránya csökkenni, míg a szolgáltató szektorban tevékenykedők részaránya növekedni kezdett. Ezek az átrendeződési folyamatok vég nélkül zajlanak, így a mai napig is tartanak. A téma aktualitását jelzi, hogy olyan meghatározó üzleti szereplők is foglalkoznak vele, mint a PwC, akik többek között a befolyásoló tényezőket vizsgálták. Az általuk készített globális vezetői felmérés szerint a mesterséges intelligencia nagyobb hatással lesz az életünkre, mint az internet, több munkahelyre lesz potenciális befolyással (PwC, 2019).

Ami a jövőt illeti, a fokozott automatizálás kilátásai - amit a mesterséges intelligencia előre törésével támogatott ipari robotok fokozott használata tükröz - arra utalnak, hogy a technológia még nagyobb hatással lehet a munkahelyek jövőjére. A WTO (2017) felhívja a figyelmet, hogy az automatizálás kockázatának kitett munkahelyek becsült aránya általában a fejlődő országokban nagyobb, mint a fejlett országokban. Nehéz következtetéseket levonni arról, hogy ez mit jelenthet a nemzeti munkaerő-piacok számára, azonban biztosak lehetünk abban, hogy a technológiai 
fejlődésnek egyrészről „romboló hatása” („desctructive effect”) van, mivel egyes készségeket elavulttá tesz, másrészről viszont magasabb szintű és új készségek igényéhez, illetve új munkahelyek létrehozásához vezet.

A tanulmány során az a célom, hogy a munkaerő-keresletre és a munkaerő-kínálatra ható, a technológiai fejlődésből származó hatásokat és összefüggéseket határozzak meg, különös tekintettel a magyarországi körülményekre, lehetőség szerint a későbbiekben javaslatokat megfogalmazva a külföldi jó gyakorlatok alapján.

\section{Az ember és a gép kapcsolata - Történelmi áttekintés}

Az elmúlt évszázadokban a technológiai változások gyakran a munkavállalói szorongások alapját szolgálták. 1811. és 1816. között Angliában a munkavállalók egy csoportja - akik „Luddistáknak” vagy „Ludditáknak” nevezték magukat - tönkretették azokat a gépeket, amelyekről azt gondolták, hogy veszélyeztetik a munkahelyüket. A 19. századi gondolkodók és közgazdászok, mint Karl Marx és David Ricardo azt jósolták, hogy a gazdaság gépesítése végső soron a munkavállalói körülményeket rontaná, megfosztva őket attól, hogy egy elfogadható szintű bérből élhessenek. Az elmúlt évszázadban John M. Keynes (az 1930-as években) és Wassily Leontief (az 1950-es években) azon félelmüket fogalmazták meg, hogy egyre több és több munkást váltanak ki gépi megoldásokkal, amely munkanélküliséghez vezet (Leontief - Duchin, 1986). Az utóbbi években Brynjolfsson és McAfee (2014) állította, hogy a jelenlévő technológiák csökkentik a munkaerő iránti keresletet és az emberi munkaerő egy részét tartós hátrányba sodorják. Azonban számos kompenzációs mechanizmus létezik, amelyek ellensúlyozhatják az automatizálás és általában a folyamatinnováció kezdeti munkaerő-kiszorító hatásait (Vivarelli, 2015). Először is, miközben a munkavállalókat kiváltják azokban az iparágakban, amelyekben bevezetik az új gépekbe épített technológiát, további munkavállalókra van szükség az új gépeket gyártó iparágakban. Másodszor, az automatizálás (és általánosságban a folyamatinnováció) csökkenti az átlagos költségeket. Acemoglu és Restrepo (2017) azt állapították meg, hogy ez egyrészről ár-termelékenységi („priceproductivity”) hatást eredményez (mivel a termelési költségek csökkennek, az iparág kibővítheti és növelheti munkaerő-igényét); és másrészről a termelés méretgazdaságossági hatásához vezet (az automatizálás miatti költségcsökkenés a teljes kibocsátás növekedéséhez vezet, és minden iparágban növeli a munkaerő iránti igényt). Hasonlóképpen, Vivarelli (2015) azzal érvel, hogy az alacsonyabb átlagköltségek alacsonyabb árakat eredményezhetnek (ha az ipar piaci struktúrája tökéletesen versenyképes), stimulálják a termékkeresletet, vagy extra nyereséget eredményezhetnek (ha az ipar szerkezete nem tökéletesen versenyképes). Ha ezeket az extra nyereségeket újra befektetik a cégbe, ez a beruházás új munkahelyeket teremthet.

\section{Az automatizálás mérhetősége}

A közgazdászok a technológiai fejlődés munkaerőpiacra gyakorolt hatását általában a következő két jelenségen keresztül szemléltetik: (1) A különböző szakképzett munkavállalókat és a munkaerő-keresletet befolyásoló új technológiák közötti kölcsönhatások jellegén és (2) a technológiai fejlődésnek a munkaerő-kínálatra és a termékpiacokra kifejtett egyensúlyi hatásai révén (Goos, 2018). 
Ezen munkaerő-kínálati kérdéskört vizsgálta Frey és Osborne (2013), akiknek a becslése szerint az Egyesült Államokban az összes munkahely 47 százaléka potenciálisan automatizálható előre nehezen meghatározható időintervallumon belül, talán egy évtized vagy két év alatt. Hasonló módszerekkel más tanulmányok is hasonló következtetésekre jutottak: az üzleti életből ismert McKinsey Global Institute (2017) szerint az amerikai foglalkozások mintegy 60 százaléka abban a helyzetben van, hogy a feladatainak legalább 30 százaléka 2055-ig automatizálható lesz, míg a Világbank (2016) becslése szerint az OECD országokban a munkahelyek közel 60 százaléka érzékeny lesz az automatizálásra a közeljövőben.

Chiacchio et al. (2018) tanulmányozták az ipari robotok foglalkoztatásra és bérekre gyakorolt hatását hat európai uniós országban, amelyek az uniós ipari robotok piacának 85,5 százalékát teszik ki. Elméletileg a robotok közvetlenül átcsopotosíthatják a munkavállalókat a konkrét feladatok elvégzéséből (elmozdulási hatás), ugyanakkor az ipari termelés hatékonysága révén is növelhetik a munkaerő-keresletet (termelékenységi hatás) (allokációs hatás, a technológiai fejlődés által éritett munkahelyeknél) Megállapították, hogy egy ezer munkavállalóra egy további robot 0,16-0,20 százalékponttal csökkenti a foglalkoztatási rátát. Ennek következtében az várható, hogy a munkáltatók oldaláról egy erősödő elmozdulás lesz a technológiai eszközök alkalmazásának irányába. Megállapításuk szerint továbbá az elmozdulási hatás különösen a középfokú végzettséggel rendelkező dolgozók és a fiatalok kohorsza esetében nyilvánvaló. Becsléseik azonban nem mutatnak robosztus és jelentős eredményeket a robotok bérnövekedésre gyakorolt hatásában, még akkor sem, ha figyelembe vették a különböző lakossági és ágazati csoportok esetleges kiegyenlítő hatásait.

Az intelligens gépek munkaerő-piacra kerülésének következtében arra számíthatunk, hogy egyes foglalkozások eltûnnek, más foglalkozások átalakulnak, de ezzel párhuzamosan újak is létrejönnek. Minden közösségben találhatunk olyan szakterületet, amely erősen kitett az automatizálhatóság veszélyének, de ezek intenzitása nagymértékben eltér. Az Egyesült Államok térségeinek 90\%-ában a potenciális gépi helyettesítési ráta (displacement rate) 22-27\% között van, míg a szórás 17-33\% között mozog. Az átlagos helyettesítési ráta az alacsony fejlettségű és vidéki területeken a legmagasabb, míg a legalacsonyabb értékeket a városi területeken láthatjuk (McKinsey, 2019).

A McKinsey által használt klaszter elemzés alapján öt földrajzi szegmens alakult ki (McKinsey, 2019):

- Városi centrum (Urban core): megavárosok és magas fejlettségű csomópontok, amelyekben magas jövedelmek szerezhetők, erős a foglalkoztatási bővülés, dinamikusak az iparágai, fiatal és jól képzett munkaerővel rendelkezik, azonban lakhatási hiány és egyenlőtlenség is jellemezi (például Los Angeles, New York, Seattle).

Városok perifériája (Urban periphery): az amerikai városok kiterjedt peremvárosai az Egyesült Államok lakosságának 15\%-ának ad otthont, akik kiélvezhetik a jól fejlődő városok növekedésének hatásait (például Riverside County (CA), Arlington County (VA), Worcester County (MA)). 
- N Niche városok: kisebb erőművek, egyetem központú és nyugdíjasok által lakott területek, amelyek erős növekedést mutatnak. Vonzó célpontot képeznek a dolgozók és a vállalatok számára is, köszönhetően az alacsony megélhetési költségeknek és a jó életszínvonalnak (például Des Moines, Naples, Ann Arbor).

Vegyes középterületek (Mixed middle): nagyjából az amerikaiak negyede él stabil városokban, kisebb, független gazdaságokban és ipari csomópontokban. Erről a csoportról egységesen egy mérsékelt növekedés mondható el (például San Diego, Salt Lake City, St. Louis)

Alacsony fejlettségű és vidéki területek: 54 város és több, mint 2000 vidéki település tartozik ebbe a kategóriába, amely az Egyesült Államok lakosságának 1/5-ét adja. Jellemző az alacsonyabb oktatási színvonal, illetve az elöregedő és csökkenő népesség (például Atlantic City, McCreary County (KY), Claiborne Parish (LA)).

\section{Nemzetközi példák a technológiai fejlődés kapcsán}

Az automatizálás munkahely-átrendező hatása tetten érhető a textiliparban is. Clifford (2013) megvizsgálta, hogy nagyjából két évtized alatt (1990-2012 között) kizárólag az Amerikai Egyesült Államokban 1,2 millió állás szűnt meg - amely a teljes iparág 3/4 részét jelenti - és került át olcsóbb munkaerő-piaci környezetbe (Kína, India és Mexikó). Azonban a folyamatosan fejlődő gépi teljesítmény lehetővé teszi, hogy a textilipari folyamatok jelentős részét emberi beavatkozás nélkül elvégezzék. A Parkdale Mills textilgyárban például 140 ember képes volt akkora termelést biztosítani 2013-ban, amelyhez 1980-ban még körülbelül 2000 embert kellett volna felvennie az üzemnek. Csupán bizonyos munkaelemek (például gépek közötti árumozgatás) igényelnek meg emberi közremúködést a gazdaságos előállítás érdekében. Ezen folyamatok következtében az amerikai textilipar visszarendeződését láthatjuk az elmúlt években, amelynek eredményeként 2009-2012 között az amerikai iparági export 37\%-kal 23 milliárd dollárra nőtt.

Az Amazon Robotics vezetője felhívja a figyelmet, hogy hiába fejlődik dinamikusan a technológia, az emberek felsőbb rendű kognitív képességei a következő években számos esetben nem lesznek kiválthatók (Fonyó, 2019). Egy egyszerűbbnek vélt rendelés teljes folyamatának ember nélküli kivitelezésére is körülbelül egy évtizedet még várni kell. Annak ellenére, hogy az Amazon már több, mint 100.000 robotot használ - elsősorban anyagmozgatásra, amelyek a padlón található vonalkódokat használják tájékozódásra és vezeték nélküli hálózaton kommunikálnak - még így is több, mint 125.000 alkalmazottja van kizárólag Észak-Amerikában. A friss élelmiszereket is magába foglaló raktárakban például egyetlen robot sem végez még munkát, abból kifolyólag, hogy nem képesek kellő módon a képi összehasonlításra (például érett gyümölcsök összehasonlítása) és a finom mozdulatokat igénylő tevékenységek ellátására (például polcokra való áruhelyezés, vagy csúszós termékek kezelése). A cég fejlesztésének a fókuszában jelenleg a szállítási és kézbesítési folyamatok korszerűsítése áll, az Amazon Prime ügyfelek rendeléseinek korábbi 2 napos kiszállítását 1 napra redukálta, amellyel párhuzamosan a megrendelés beérkezését követő 4 órán belül a terméknek el kell hagynia a raktárt. Az érintett tevékenységek volumenét az szemlélteti, hogy csupán egyetlen nagy cégnek, az Amazonnak, kizárólag az Egyesült Államokban 110 nagy raktárja, 45 helyszíni áruválogatója és 50 kiszállítást végző állomása van. 
Underwood (2018) cikkében felhívja rá a figyelmet, hogy már nem csak azoknak a rutinmozdulatoknak az elvégzésére alkalmasok a technológia vívmányai, mint amelyeket tipikusan egy gyárban dolgozó operátor végez, hanem kreativitást igénylő munkakörökben is, mint például az újságírás. A szerző konkrét példákon szemlélteti azt, hogy a legnagyobb szereplők (New York Times, Washington Post, Reuter, BBC) már évek óta fejleszt mesterséges intelligenciára épülő szoftvereket, amelyek a média munkafolyamatainak egyszerüsítését, hétköznapi feladatok automatizálását, több információ hatékony feldolgozását, hamis hírek megszüntetését és gépek által írott cikkek megjelenését szolgálják.

\section{Magyarország munkaerőpiaca a technológiai fejlődés tükrében}

2016. év végén az MKIK Gazdaság- és Vállalkozáskutató Intézet Magyarországon vizsgálta az automatizációs kitettséget. A jelenleg használható és tesztelt automatizációs rendszerek figyelembe vételével azt az eredményt kapták, hogy országosan a munkahelyek $12 \%$-át jelenleg is ki lehetne váltani gépi technológiával (amely 55 foglalkozást jelent), ami több mint 513 ezer ember állását érintené. Az érintett foglalkozások többsége (körülbelül 1/3-a) az iparban (azon belül is a feldolgozóiparban), nagyjából 20-20\%-a adminisztrációs, illetve logisztikai és járművezetési tevékenységekhez köthető, míg a fennmaradó kicsivel több, mint 20\%-on az építőipar és a szolgáltatások csoportja osztozik. Az automatizálható állások aránya vidéken magasabb (13\%), mint a főváros esetén (10\%), tehát vidéken több olyan munkahely található, amely gépesíthető lenne (Nábelek et al., 2016).

Nábelek és Vági (2019) megvizsgálták a NAV-os nyilvántartások alapján, hogy Magyarországon járási szinten hány olyan foglalkozás van, amelyet a FEOR leírások alapján automatizálható és többségében automatizálható részfeladatok alkotnak. Vizsgálatukban azt találták, hogy a FEORban nyilvántartott 485 foglalkozás közül Magyarországon 90 többségében automatizálható részfeladatokból áll, míg 26 teljesen automatizálható. Az 1. ábra összefoglalja, hogy a szerzők milyen kapcsolatot találtak a képzettségen és az iparágakon belüli automatizálhatóságra. A legnagyobb kitettsége az automatizálható foglalkozások közül szakképesítést nem igénylő foglalkozásoknak van, ugyanis itt a szakmák harmada az automatizálható kategóriában található. Az összes foglalkoztatotthoz viszonyítva az mondható el, hogy a magyar emberek 4\%-a automatizálható és 15\%-a többségében automatizálható részfeladatokból álló munkahelyen dolgozik, míg a hazai szakmák csupán 18\%-a tartozik a nem automatizálható csoportba. 
International Journal of Engineering and Management Sciences (IJEMS) Vol. 5. (2020). No. 1

DOI: $10.21791 /$ IJEMS.2020.1.5

Szakképzettséget nem igénylő egyszerű foglalkozások

Ipari és építőipari foglalkozások

Gépkezelők, összeszerelők, járművezetők

Irodai és ügyviteli, ügyfélkapcsolati foglalkozások

Mezőgazdasági és erdőgazdálkodási foglalkozások

Kereskedelmi és szolgáltatási foglalkozások

Egyéb felsőfokú vagy középfokú képzetsséget igénylő foglalkozások

Felsőfokú képzettség önálló alkalmazását igénylő foglalkozások

nem automatizálható

részben automatizálható

automatizálható

1. ábra. Az egyes automatizációs kategóriákhoz tartozó foglalkozások aránya a FEOR-ban nyilvántartott foglalkozás föcsoportok szerint

Forrás: Nábelek - Vági, 2019

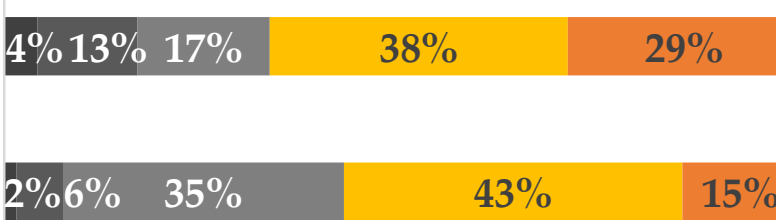

\begin{tabular}{|lrlr|}
\hline $2 \% 13 \%$ & $34 \%$ & $40 \%$ & $11 \%$ \\
\hline $9 \%$ & $35 \%$ & $48 \%$ & $9 \%$
\end{tabular}

$19 \% \quad 19 \% \quad 56 \% \quad 6 \%$

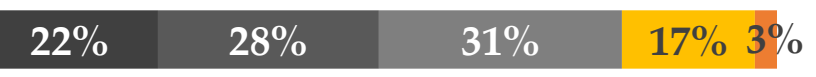

$30 \%$ $36 \%$ $26 \% \quad 8 \%$

$80 \%$ $17 \% 3^{\circ}$

0\% $10 \%$ 20\% 30\% 40\% 50\% 60\% 70\% 80\% 90\% 100\% - többségében nem automatizálható részfeladatok többségében automatizálható részfeladatok

\section{Összegzés}

A dolgozatban jól látható, hogy a technológiai fejlődés több, korábban nem prognosztizált területen jelentős hatást képes kifejteni. Ebből kifolyólag számíthatunk rá, hogy az ágazati átrendeződések a következő években sem fognak enyhülni, sőt némi fokozódás is várható az intelligens eszközök számítási és ellenőrzési kapacitásának növekedése következtében. Nem véletlen az sem, hogy az utolsó részben ismertetetett két hazai felmérés között csupán 3 év elteltét követően is növekedett a meglévő technológiákkal potenciálisan automatizálható foglalkozások száma. Ennek köszönhetően az érintett iparágak és nemzeti munkaerő-piaci szereplők nem dőlhetnek hátra, hanem fokozottan figyelniük kell a változások tendenciáját és előre fel kell készülniük (akár stratégiai módosításokat, vagy oktatási tevékenységet fokozva) a következő évek kihívásaira. 
International Journal of Engineering and Management Sciences (IJEMS) Vol. 5. (2020). No. 1

DOI: 10.21791/IJEMS.2020.1.5

\section{Hivatkozások}

[1] Acemoglu, D. and Restrepo, P. (2017): Robots and Jobs: Evidence from US Labor Markets. NBER Working Paper 23285. szám, Cambridge, MA: National Bureau of Economic Research (NBER).

[2] Brynjolfsson, E. and McAfee, A. (2014): The Second Machine Age: Work, Progress, and Prosperity in a Time of Brilliant Technologies. New York: WW Norton and Co.

[3] Chiacchio, F. - Petropoulos, G. - Pichler, D. (2018): The Impact of Industrial Robots on EU employment and Wages: A Local Labour Market Approach. Working Paper, Bruegel, 2. szám, $1-35$.

[4] Clifford, S. (2013): U.S. textile plants return, with floors largely empty of people. The New York Times, 2013.09.12., Elérhető: https://www.nytimes.com/2013/09/20/business/ustextile-factories-return.html Letöltve: 2019.10.17.

[5] Fonyó, I. (2019): Az Amazon egy csomó feladatot nem bízna rá a robotokra. Tudományos és műszaki tájékoztatás, 66. évf. 5. szám, 301-302.

[6] Ford, M. (2017): Robotok kora. Milyen lesz a világ munkahelyek nélkül? HVG Kiadó Zrt., Budapest.

[7] Frey, C. B. - Osborne, M. A. (2013): The future of employment: How susceptible are jobs to computerisation?. Technological Forecasting and Social Change, 48. évf. 114. szám, 254-280.

[8] Goos, M. (2018): The impact of technological progress on labour markets: policy challenges. Oxford Review of Economic Policy, 34. évf. 3. szám, 362-375.

[9] Leontief, W. - Duchin, F (1986): The Future Impact of Automation on Workers. New York Oxford, Oxford University Press.

[10] McKinsey Global Institute (2017): A Future that Work: Automation, Employment and Productivity, McKinsey \& Company. Elérhető: https://www.mckinsey.com/ /media/mckinsey/featured\%20insights/Digital\%20Disrup tion/Harnessing\%20automation\%20for\%20a\%20future\%20that\%20works/MGI-Afuture-that-works-Executive-summary.ashx Letöltve: 2019.12.12.

[11] McKinsey Global Institute (2019): The future of work in America: People and places, today and tomorrow. Elérhető: https://www.mckinsey.com/featured-insights/future-ofwork/the-future-of-work-in-america-people-and-places-today-and-tomorrow Letöltve: 2019.12.12. 
International Journal of Engineering and Management Sciences (IJEMS) Vol. 5. (2020). No. 1

DOI: $10.21791 /$ IJEMS.2020.1.5

[12] PwC (2019): 22nd Annual Global CEO Survey. Elérhető: https://www.pwc.com/gx/en/ceosurvey/2019/report/pwc-22nd-annual-global-ceo-survey.pdf Letöltve: 2019.12.12.

[13] Nábelek, F. - Sturcz, A. - Tóth, I. J. (2016): Az automatizáció munkaerô-piaci hatásai: Járási munkaerő-piacok automatizációs kitettségének becslése. MKIK Gazdaság- és Vállalkozáskutató Intézet. Elérhető: https://epale.ec.europa.eu/sites/default/files/gvi__a_munka_jovoje_2016_elemzes_161023_2-1.pdf Letöltve: 2019.12.12.

[14] Nábelek, F. - Vági, E. (2019): A szakmák automatizálhatósága és az automatizáció lehetséges munkaerőpiaci hatásai Magyarországon. MKIK Gazdaság- és Vállalkozáskutató Intézet. Elérhető: $\quad$ https://gvi.hu/kutatas/587/a-szakmak-automatizalhatosaga-es-azautomatizacio-lehetseges-munkaeropiaci-hatasai-magyarorszagon Letöltve: 2019.12.12.

[15] Underwood, C. (2018): Automated Journalism -AI Applications at New York Times, Reuters, and Other Media Giants Elérhető: https://emerj.com/ai-sector-overviews/automatedjournalism-applications/ Letöltve: 2019.10.17.

[16] Világbank (2016): Digital Dividends, World Development Report 2016, Washington, DC, World Bank. Elérhető: http://documents.worldbank.org/curated/en/896971468194972881/pdf/102725-PUBReplacement-PUBLIC.pdf Letöltve: 2019.12.12.

[17] Vivarelli, M. (2015): Innovation and Employment. IZA World of Labour 154. szám, 1-10.

[18] WTO (2017): World trade report 2017 - Trade, technology and jobs. Elérhető: https://www.wto.org/english/res_e/booksp_e/world_trade_report17_e.pdf Letöltve: 2019.12.12. 